\title{
A novel tetramethylnaphthalene derivative synergistically inhibits HTLV-1-infected cell proliferation in combination with cepharanthine
}

\author{
Masaaki Toyama ${ }^{1 *}$, Takayuki Hamasaki ${ }^{1}$, Tomofumi Uto ${ }^{1}$, Hiroshi Aoyama², Mika Okamoto', Yuichi Hashimoto², \\ Masanori Baba ${ }^{1}$
}

From 15th International Conference on Human Retroviruses: HTLV and Related Viruses

Leuven and Gembloux, Belgium. 5-8 June 2011

\section{Background}

We have previously found that the novel tetramethylnaphthalene derivative TMNAA selectively inhibits the proliferation of HTLV-1-infected T-cell lines but not HTLV-1-uninfected T-cell lines. Although its target molecule is still unknown, TMNAA did not affect NF$\kappa \mathrm{B}$ activity. Therefore, we further examined the antiproliferative activity of TMNAA against various $\mathrm{T}$-cell lines in combination with cepharanthine (CEP), which is known to inhibit NF- $\kappa$ B.

\section{Materials and methods}

HTLV-1-infected and uninfected T-cell lines were cultured in the presence of various concentrations of TMNAA and CEP, and their proliferation and viability were determined by a tetrazolium dye method. The mode of cell death was also examined by flow cytometry and Western blot analysis.

\section{Results}

The 50\% inhibitory concentrations (IC50s) of TMNAA and CEP for the ATL cell line (S1T) were $1.65 \pm 0.03$ and $1.97 \pm 0.29 \mu \mathrm{M}$, respectively. On the other hand, the IC50 of TMNAA and CEP combination resulted in $0.93 \pm 0.13 \mu \mathrm{M}$, indicating that the combination synergistically inhibited the proliferation of S1T cells. Such synergism was observed for another infected cell line (MT-2) but not for HTLV-1-uninfected cell lines. Moreover, TMNAA did not induce apoptosis of S1T cells, but CEP did. Interestingly, TMNAA significantly

\footnotetext{
* Correspondence: toyama@m2.kufm.kagoshima-u.ac.jp

${ }^{1}$ Center for Chronic Viral Diseases, Kagoshima University, Kagoshima 890-8544, Japan

Full list of author information is available at the end of the article
}

enhanced the CEP-induced apoptosis of S1T and MT-2 cells.

\section{Conclusions}

The combination of TMNAA and CEP selectively inhibits the proliferation of HTLV-1-infected cell lines through the induction of apoptosis. Therefore, TMNAA and CEP may have potential for chemotherapy of ATL.

\section{Author details \\ 'Center for Chronic Viral Diseases, Kagoshima University, Kagoshima 890-8544, Japan. ${ }^{2}$ Institute of Molecular and Cellular Biosciences, The University of Tokyo, Tokyo 113-0032, Japan.}

Published: 6 June 2011

doi:10.1186/1742-4690-8-S1-A64

Cite this article as: Toyama et al:: A novel tetramethylnaphthalene derivative synergistically inhibits HTLV-1-infected cell proliferation in combination with cepharanthine. Retrovirology 2011 8(Suppl 1):A64.

Submit your next manuscript to BioMed Central and take full advantage of:

- Convenient online submission

- Thorough peer review

- No space constraints or color figure charges

- Immediate publication on acceptance

- Inclusion in PubMed, CAS, Scopus and Google Scholar

- Research which is freely available for redistribution 